\title{
How Important are Cereals and Cereal Products in the Average Polish Diet?
}

\author{
Wacław Laskowski@, Hanna Górska-Warsewicz *®i, Krystyna Rejman $₫$, \\ Maksymilian Czeczotko and Justyna Zwolińska
}

Department of Organization and Consumption Economics, Faculty of Human Nutrition and Consumer Sciences, Warsaw University of Life Sciences, 02-787 Warsaw, Poland; waclaw_laskowski@sggw.pl (W.L.);

krystyna_rejman@sggw.pl (K.R.); makysmilian_czeczotko@sggw.pl (M.C.); justyn.zwolinska@gmail.com (J.Z.)

* Correspondence: hanna_gorska_warsewicz@sggw.pl; Tel.: +48-22-5937144

Received: 31 January 2019; Accepted: 19 March 2019; Published: 21 March 2019

check for updates

\begin{abstract}
The main aim of this study was to identify the food sources of energy and 28 nutrients from cereals and cereal products in the average Polish diet based on data from a nationally representative sample of the Polish population attending in 2016 Household Budget Survey (i.e., 36,886 households). The contribution of energy and nutrients from cereals and cereal products were compared with reference values. The detailded analysis included five main groups and nine sub-groups of cereal food category. Our findings indicated that cereals and cereal products contributed $30.4 \%$ of total dietary energy supply, providing a significant percentage of six nutrients to the average Polish diet (i.e., $64.1 \%$ of manganese, $51 \%$ of carbohydrates, $48.5 \%$ of dietary fibre, $34.1 \%$ of iron, $33.6 \%$ of folate, and $31.3 \%$ of copper). Supply at the level of $20-30 \%$ was observed for protein, thiamin, phosphorus and zinc, and at 10-20\% for polyunsaturated fatty acids (PUFA), sodium, potassium, calcium, riboflavin, niacin, and vitamin B6. For other nutrients i.e., total fat, saturated fatty acids (SFA), monounsaturated fatty acids (MUFA), cholesterol, iodine, vitamins: A, D, B12, and C, the share of cereals and cereal products contribution was below $10 \%$. Cereals and cereal products were the major food category in meeting the reference values for the Polish population in case of manganese, carbohydrates (approximately 100\%), and sodium (50\%). The reference values was reached at the level of 30-40\% for dietary fibre, protein, iron, copper, zinc, phosphorus and thiamin, and $20-30 \%$ for energy, magnesium, folate, niacin, riboflavin, vitamins B6 and E. For such nutrients as total fat, SFA, and potassium, the fulfillment of the reference values amounted to $10-20 \%$. Our results document the importance of cereals and cereal products in the Polish diet, which should be emphasized from a nutritional and health point of view.
\end{abstract}

Keywords: cereals; cereal products; energy intake; nutrient intake; food sources; household budget survey

\section{Introduction}

Cereals and cereal products are staple foods in most human diets [1-3], in both developed and developing countries, providing a major proportion of dietary energy and nutrients. They are composed of approximately $75 \%$ carbohydrates, mainly starches and about $6-15 \%$ protein, contributing in global terms more than $50 \%$ of energy supply [4]. The importance of cereals and cereal products is also supported by the fact that global food security depends to the greatest degree on cereal production, which yearly amounts to approximately 2600 million tons [5].

The role of cereals and cereal products are frequently analyzed in the scientific literature in relation to the level of consumption and the nutritional value [6-8]. Some cereal products (breads, rolls and tortillas, ready-to-eat cereals, quick breads and bread products) are described as contributors 
of folate, iron, thiamin, niacin, dietary fibre [6], manganese and zinc $[9,10]$. Consumption of whole grain cereal products is associated with higher diet quality and nutrient-dense foods delivering protein, lipids, B vitamins (including thiamin, niacin, riboflavin), vitamin E, and minerals (calcium, magnesium, potassium, phosphorus, iron, and sodium) [7]. The bioavailability of manganese should be emphasized [11] due to its role in metabolic processes [10,12-17] as well as the functioning of nervous, immunological and reproductive systems [14-16]. Many studies have described the negative effect of phytates, which are natural substance found in cereals and cereal products, on the bioavailability of minerals and trace elements. The interaction between phytic acid and minerals should be taken into consideration to ensure high bioavailability and adequate supply of them [11].

Currently, the importance of cereals in the diet, particularly wholegrain ones, is being explored due to the presence of dietary fibre and bioactive compounds. Dietary fibre components are unevenly distributed in a grain and their highest concentration occurs in the outer tissues [18]. Whole kernel or coarsely milled grains contain more dietary fibre and phytochemicals with potential anti-inflammatory and antioxidant properties than refined grains [19]. On the basis of a series of systematic reviews and meta-analyses, it can be stated that there is substantial epidemiologic evidence that dietary fibre and wholegrain foods are associated with decreased risk of diet-related non-communicable diseases (DRNCD) [20-24]. Diet with high levels of dietary fibre and whole grains result in reduced risk of all-cause and cardiovascular related mortality [21-23,25-28], atherosclerotic cardiovascular diseases [21,23,29-33], ischemic stroke [27,32,34], type 2 diabetes [21,23,30,33,35,36], obesity [29], and some types of cancers $[21,23,27,30,33,37,38]$. Dietary fibre and resistant starch provide substrate for colonic microbial fermentation, leading to the production of short chain fatty acids that are a direct energy source for the colonic epithelium and influence hepatic insulin sensitivity [18]. The importance of dietary fibre in the prevention of colorectal cancer remains controversial. However, studies conducted on large population samples showed that high intakes of dietary fibre, especially from grains, cereals, and whole grain cereal foods are associated with reduced risks of colorectal $[23,28,39-42]$ and gastric cancer $[33,41]$. Many other studies strengthen the evidence for dietary fibre protective role in the prevention of colon and/or rectum cancer [43-47]. An inverse association has been observed between consumption of whole grains and cereal fibre and a reduction of total and cause-specific mortality [25]. However, according to the newest World Cancer Research Fund International report the role of whole grains consumption in reducing the risk of colorectal cancer is not yet convincing. However, scientific findings have allowed the statement that whole grains probably decrease the risk of these types of cancer [48].

The importance of cereals, especially whole grains, in the prevention of the DRNCD is especially important due to the three stages of the nutrition transition process which are revealed in changing dietary patterns and lifestyle resulting from rapid economic growth $[4,49]$. The first stage has occurred in both developed and developing countries and is known as the "expansion" effect [50] or "receding famine" with higher consumption of cheaper food of vegetable origin: starchy, low fat, high dietary fibre and low variety [49]. This is accompanied by improvements in food availability and the significant rise in dietary energy supply observed globally and the gradual elimination of dietary deficiencies, thus improving the overall nutritional status of the population [4]. The second stage ("substitution effect") results in a shift in the structure of food consumption with no major change in the overall energy supply. This shift is primarily from carbohydrate-rich staples to vegetable oils, animal products and sugar [51]. In the second stage DRNCDs predominate, as a result of an energy-dense diets that are high in total fat, cholesterol, sugar and other refined carbohydrates, and low in polyunsaturated fatty acids and dietary fibre, that are often accompanied by an increasingly sedentary lifestyle [49]. Rapid urbanization has become the main driving force behind this qualitative nutrition transition stage, followed by technological changes, facilitating work and leisure, food processing development, mass media growth [49,52], food marketing, and the policies of trade liberalization [51]. The prevalence of diet-related diseases together with global population growth and the imbalance of ecosystems determine the shift to the next stage of nutrition transition. To change diet to being more sustainable, 
which are profitable both for the people and the planet is the immediate challenge. The EAT-Lancet Commission, a multinational initiative launched for food system transformation, describes an universal healthy reference diet based on sustainable consumption rules. This diet focuses on an increase in consumption of healthy foods, such as vegetables, fruits, whole grains, legumes, and nuts, and a decrease in consumption of unhealthy foods, such as red meat, sugar, and refined grains that would provide major health benefits [53].

In terms of the importance of cereals and changes in food consumption patterns, it should be highlighted that the analysis of energy and nutrient sources is crucial to assure the adequate nutritional quality of diets. The aim of this study was to identify food sources of energy and 28 nutrients from cereals and cereal products based on data from a representative sample of the Polish population drawn by the Central Statistical Office for the purpose of Household Budget Survey in 2016. The results of the contribution of energy and nutrients were compared with reference values for the Polish population.

\section{Methods}

\subsection{Study Overview}

Sources of energy and nutrient supply from cereals and cereal products were studied. The analysis covers energy and 28 nutrients: carbohydrates, dietary fibre, protein, total fat, saturated fatty acids (SFA), monounsaturated fatty acids (MUFA), polyunsaturated fatty acids (PUFA), cholesterol, calcium, phosphorus, sodium, potassium, magnesium, iron, zinc, copper, manganese, iodine, thiamin, riboflavin, niacin, folate, and vitamins B12, B6, A, D, E, and C.

The research process is presented in Figure 1 and described in Sections 2.2-2.6.

\subsection{Sample Selection Method}

The Household Budget Survey (HBS), a representative method of data collection in Poland is organized and conducted by the Central Statistical Office, Social Surveys and Living Conditions Statistics Department in cooperation with the Regional Statistical Office in Łódź. In 2016, 36,886 households (total number of persons $n=99,230$ ) participated in the HBS [54]. Each household kept records of expenditures, quantitative consumption and revenues in a special budget diary (paper booklet or electronic version available through Internet browser) for one month [54,55]. Surveys of households are conducted using a representative method based on a random sample, which gives the opportunity to generalize the obtained results for all households in the country. Since 1993, the HBS has been conducted using a total monthly rotation in a quarterly cycle. The "quarterly cycle" involves an additional interview conducted with households surveyed at the end of the quarter $[54,55]$. Additionally, in the case of non-response, the methods of a random replacement of households and sequential sampling were applied. For this purpose, the Central Statistical Office (CSO) uses two lists of households (first selection and reserve) to achieve the planned sample size and representativeness [55]. Detailed information related to sample selection process was published in our previous studies [56,57].

The data on each household participating in the survey are based on the "Household Budget Diary" and the questionnaire "Household's Statistical Sheet". The household budget survey is conducted by interviewers who are employees of statistical offices in voivodships (administrative regions of Poland; in EU statistics they correspond to NUTS2 type units). Their main tasks are as follows [54]:

- to visit every household at least four times a month, give instructions how to collect data and explain doubts;

- to conduct an interview in every household at the end of the month on income, expenses and living conditions;

- to collect, control and analyze the data recorded by the household;

- $\quad$ to enter data into the CSO system; 
- to conduct interviews in quarterly cycle regarding household equipment, fixed assets and real estate.

\begin{tabular}{|c|c|}
\hline $\begin{array}{l}\text { Central Statistical Office } \\
\text { (CSO) } \\
\text { Household Budget Survey } \\
\text { (HBS) } \\
\text { (Section 2.2) }\end{array}$ & $\begin{array}{l}\text { 1. Random selection of areas survey points based on } \\
\text { the list of statistical regions developed in Poland } \\
\text { for National Census purposes } \\
\text { 2. Random selection of representative sample of } \\
\text { households }\end{array}$ \\
\hline \multicolumn{2}{|l|}{ V } \\
\hline \multicolumn{2}{|c|}{$\begin{array}{l}\text { Data base of } 36,886 \text { households (Section } 2.3 \text { ) } \\
\text { - quantity of purchase and consumption of food products in } 91 \text { sub-groups } \\
\text { (in grams, kilograms, liters) per month in each household }\end{array}$} \\
\hline \multicolumn{2}{|l|}{ 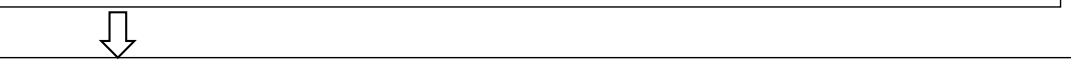 } \\
\hline $\begin{array}{l}\text { Conversion of consumpt } \\
\text { (Section 2.3) }\end{array}$ & into one person per month in each household \\
\hline
\end{tabular}

1. "Nutritive Value Tables for Foods and Meals" (4th ed.)

2. R program (v 3.0.2)

(Section 2.4)

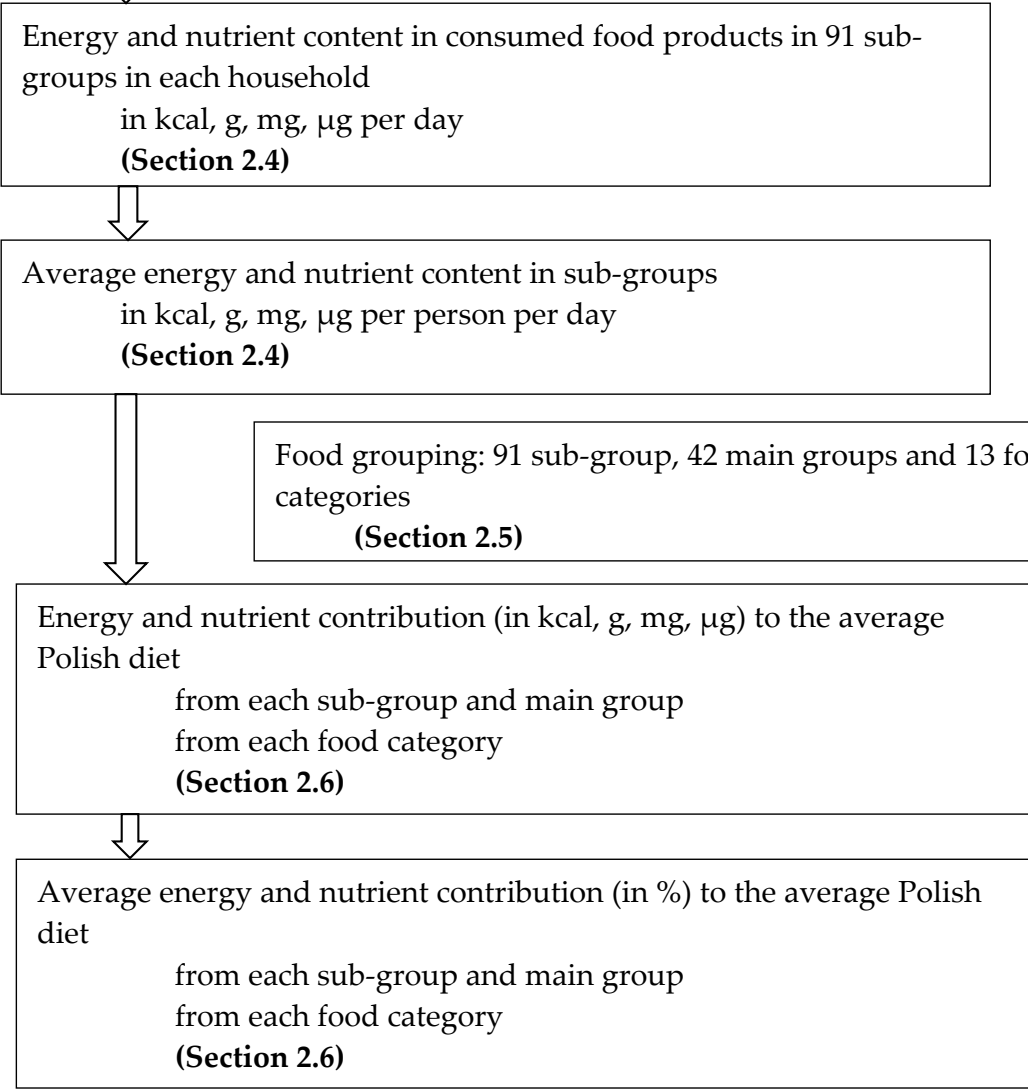

Figure 1. Research process.

\subsection{Food Consumption Data}

The basis for the calculations was the detailed data from each of the 36,886 households with information characterizing households (i.e., location, income, education level, etc.) and data on purchased and consumed products in terms of quantity (in grams, kilograms, liters) and value (in Polish zloty). Food grouping was presented in our previous article [57] and is included in Supplemental Table S1. Data on the consumption were converted into one person per month, using the number 
of persons in the household and the number of days of in-home nutrition. According to the CSO methodology, the moment of consumption of food products is the moment of their acquisition by a household. For each of the 91 sub-groups we have received the amount of consumption expressed in grams, kilograms or liters per 1 person per one month and day. These data were the basis to determine the nutritional density of the average Polish diet [58], and to identify the food sources of nutrients [56,57].

In this study we analyzed cereals and cereal products as a source of energy and 28 nutrients.

\subsection{Energy and Nutrient Content-Statistical Calculations and Method}

To convert the amount of consumption of a particular food product expressed in grams, kilograms and liters into energy (in $\mathrm{kcal}$ ) and nutrients content (in $\mathrm{mg}, \mu \mathrm{g}$ ) we used:

1. "Nutritive Value Tables for Foods and Meals" (4th ed.) [59]—the official in Poland food composition tables;

2. R program (v 3.0.2, The R Foundation for Statistical Computing, Vienna, Austria), system and environment for statistical computation [60-62].

Such a conversion was made for each of sub-groups in two stages: first for each household, and then as an average value per statistical person in each household.

The "Nutritive Value Tables for Foods and Meals" [59] were developed and updated in 2017 by the National Food and Nutrition Institute. From the database of 1100 products and assortment items, we used 930 products. The average energy and nutrient content were calculated considering, if necessary, the weights resulting from the known or estimated proportion of the consumption of the product relative to the others in the group [58].

The $\mathrm{R}$ environment is a computer language and an integrated software facility for data calculation, implementation of statistical techniques and graphical display [60-62]. It allows the integration of the HBS database and data from "Nutritive Value Tables for Foods and Meals" to calculate the average intake of energy and nutrients using special writing functions. The weight of corrections was implemented to improve the representativeness of the results and account for the size of the household. This allowed us to consider the results as being representative for the population of Poland $[58,63]$.

In addition, energy and nutrient supply were compared to the reference values. For this purpose, we used the reference values for energy and nutrients for the Polish population, developed and published by the National Food and Nutrition Institute [64]. Results were presented as a percentage of fulfillment of the reference values for energy and 28 nutrients.

\subsection{Food Grouping}

Food products were aggregated into 91 sub-groups, 42 main groups and 13 categories (Table S1). The classification has been modified and published previously [54,65-68]. For this study the food category "cereals and cereal products" was broken into five main and nine sub-groups as shown in Table 1.

\subsection{Results Format}

For the purpose of this study, the level of supply of energy and 28 nutrients were calculated for one cereal food category; five main groups; and nine detailed sub-groups.

The mean nutrient intake from these foods was expressed as a percentage of the total dietary intake of the analyzed nutrient and ranked in descending order. A three-stage method of presenting the results was adopted:

(1) the amount of consumption of cereals and cereal products-Section 3.1

(2) the amount of intake, the share of main groups from the cereal category in terms of their contribution to energy and 28 nutrients intake, and the share (\%) in fulfillment of reference 
values-Section 3.2 (energy), Section 3.3 (macronutrients), Section 3.4 (minerals), and Section 3.5 (vitamins)

(3) share of five main groups and nine sub-groups from the cereal category in terms of their contribution to intake of energy and 28 nutrients - Supplemental Tables S1-S30.

Table 1. Main groups and sub-groups in the category of cereals and cereal products.

\begin{tabular}{cc}
\hline Main Groups & Sub-Groups \\
\hline rice, cooked grains & rice \\
\hline bread, rolls, bread products & groats and cereal grains \\
\cline { 2 - 2 } pizza, pasta and other flour dishes & quick breads and other bread products \\
\hline flour, bran, cooking ingredients & pizza and other flour dishes \\
\hline ready-to-eat cereals & wheat flour \\
\hline
\end{tabular}

\section{Results}

Average consumption of cereal products is presented in Table 2. Food sources of energy and 28 nutrients from cereals and cereal products are shown in Tables 3-7 and Figure 2, as well as in the Supplemental Tables S2-S30.

\subsection{Cereal and Cereal Product Consumption}

Consumption of cereals and cereal products is presented in Table 2. The consumption of these products is dominated by bread and rolls with a quantity of almost 130 grams per person per day. Second place in the ranking was taken by products which are substitutes for fresh bread (quick bread and bread products). It is worth noting that wheat flour turned out to be the third group in terms of amount consumed. This indicates that the preparation of traditional flour dishes (such as pancakes, macaroni, many types of dumplings, gnocchi, crumpets etc.), sweet bakes (cakes, pies, cupcakes, torts, etc.) as well as bread is still practiced in Polish households, especially in small cities and rural areas [69].

Table 2. Average consumption of cereals and cereal products in Polish households.

\begin{tabular}{ccc}
\hline \multirow{2}{*}{ Sub-Groups of Cereal Products } & \multicolumn{2}{c}{ Average Consumption } \\
& g per Person per Month & g per Person per Day \\
\hline bread and rolls & 3884 & 129.5 \\
quick breads and other bread products & 984 & 32.8 \\
wheat flour & 719 & 24.0 \\
pasta, macaroni, noodles & 420 & 14.0 \\
rice & 180 & 6.0 \\
breakfast cereals & 166 & 5.5 \\
groats and cereal grains & 142 & 4.7 \\
pizza and other flour dishes & 128 & 4.3 \\
other flours & 16 & 0.5 \\
\hline
\end{tabular}


Table 3. Contribution of energy (\%) from main cereal food groups and sub-groups in the average Polish diet.

\begin{tabular}{cccc}
\hline Specification & Energy, $\%$ & Main Group Rank & Sub-Group Rank \\
\hline Bread, rolls, bread products & 21.9 & 1 & \\
\hline Bread and rolls & 16.4 & & 1 \\
Quick breads and other bread products & 5.5 & 2 & 3 \\
\hline Flour, bran, cooking ingredients & 3.4 & & 9 \\
\hline Wheat flour & 3.3 & 3 & 4 \\
Other flours & 0.1 & & \\
\hline Pizza, pasta and other flour dishes & 2.6 & 4 & 6 \\
\hline Pasta, macaroni, noodles & 2.1 & & 7 \\
\hline Pizza and other flour dishes & 0.5 & & 5 \\
\hline Rice, cooked grains & 1.6 & 5 & \\
\hline Rice & 0.9 & & \\
\hline Ready-to-eat cereal (breakfast cereals) & 1.0 & & \\
\hline Total & 30.4 & & \\
\hline
\end{tabular}

Table 4. Macronutrients, dietary fibre, fatty acids and cholesterol: contribution by cereals and cereal products to the average Polish, top three main groups and fulfillment of the reference values.

\begin{tabular}{|c|c|c|c|c|c|c|c|}
\hline \multirow[t]{2}{*}{ Nutrients } & \multirow{2}{*}{$\begin{array}{c}\text { Average } \\
\text { Polish } \\
\text { Diet }\end{array}$} & \multicolumn{2}{|c|}{$\begin{array}{l}\text { Cereals and Cereal } \\
\text { Products in }\end{array}$} & \multirow{2}{*}{$\begin{array}{l}\text { Bread, Rolls, } \\
\text { Bread } \\
\text { Products, \% }\end{array}$} & \multirow{2}{*}{$\begin{array}{l}\text { Flour, Bran, } \\
\text { Cooking } \\
\text { Ingredients, \% }\end{array}$} & \multirow{2}{*}{$\begin{array}{l}\text { Pizza, Pasta, } \\
\text { Other Flour } \\
\text { Dishes, } \%\end{array}$} & \multirow{2}{*}{$\begin{array}{c}\text { Fulfillment of } \\
\text { Reference } \\
\text { Values, \% }\end{array}$} \\
\hline & & g or mg & $\%$ & & & & \\
\hline Dietary fibre & $17.6 \mathrm{~g}$ & $8.5 \mathrm{~g}$ & 48.5 & 35.4 & 4.4 & (1) & 35.9 \\
\hline Protein & $77.9 \mathrm{~g}$ & $18.6 \mathrm{~g}$ & 23.9 & 16.5 & 3.1 & 2.5 & 30.0 \\
\hline PUFA & $17.9 \mathrm{~g}$ & $9.6 \mathrm{~g}$ & 17.4 & 13.6 & 1.4 & 1.2 & n.a. \\
\hline SFA & $34.8 \mathrm{~g}$ & $3.1 \mathrm{~g}$ & 8.2 & 6.9 & 0.2 & 0.8 & $15.9 \%$ \\
\hline Cholesterol & $316 \mathrm{mg}$ & $20.2 \mathrm{mg}$ & 6.4 & 4.2 & 0 & 2.2 & n.a. \\
\hline
\end{tabular}

(1) The third largest contributor were ready-to-eat cereals with $0.3 \%$ for MUFA and $3.2 \%$ for dietary fibre; n.a.: reference value not available.

Table 5. Minerals: contribution by cereals and cereal products to the average Polish diet, top two main groups and fulfillment of the reference values.

\begin{tabular}{|c|c|c|c|c|c|c|}
\hline \multirow[t]{2}{*}{ Nutrients } & \multirow{2}{*}{$\begin{array}{c}\text { Average } \\
\text { Polish Diet }\end{array}$} & \multicolumn{2}{|c|}{$\begin{array}{l}\text { Cereals and Cereal } \\
\text { Products in }\end{array}$} & \multirow{2}{*}{$\begin{array}{l}\text { Bread, Rolls } \\
\text { Bread } \\
\text { Products, \% }\end{array}$} & \multirow{2}{*}{$\begin{array}{l}\text { Flour, Bran, } \\
\text { Cooking } \\
\text { Ingredients, \% }\end{array}$} & \multirow{2}{*}{$\begin{array}{c}\text { Fulfillment of } \\
\text { Reference Values, } \\
\%\end{array}$} \\
\hline & & mg or $\mu \mathrm{g}$ & $\%$ & & & \\
\hline iron & $10.3 \mathrm{mg}$ & $3.5 \mathrm{mg}$ & 34.1 & 24.9 & 3.3 & 30.7 \\
\hline copper & $1.1 \mathrm{mg}$ & $0.4 \mathrm{mg}$ & 31.3 & 22.1 & 2.6 & 39.0 \\
\hline phosphorus & $1160.2 \mathrm{mg}$ & $289.9 \mathrm{mg}$ & 25.0 & 17.6 & 2.1 & 39.3 \\
\hline sodium & $3863.8 \mathrm{mg}$ & $710.6 \mathrm{mg}$ & 18.4 & 17.5 & (1) & 50.1 \\
\hline potassium & $2617.9 \mathrm{mg}$ & $435.6 \mathrm{mg}$ & 16.6 & 12.2 & 1.4 & 12.9 \\
\hline calcium & $644.1 \mathrm{mg}$ & $77.0 \mathrm{mg}$ & 12.0 & 8.8 & 0.8 & 6.5 \\
\hline iodine & $154.6 \mu \mathrm{g}$ & $10.2 \mu \mathrm{g}$ & 6.6 & 5.6 & 0.3 & 6.3 \\
\hline
\end{tabular}

(1) Second largest contributor were ready-to-eat cereals with 0.5\%; (2) Second largest contributor was rice and cooked grains with $2.7 \%$ for magnesium and $4.5 \%$ for manganese. 
Table 6. Vitamins: contribution by cereals and cereal products to the average Polish, their top two main groups and fulfillment of the reference values.

\begin{tabular}{|c|c|c|c|c|c|c|c|}
\hline \multirow[t]{2}{*}{ Nutrients } & \multirow{2}{*}{$\begin{array}{c}\text { Average } \\
\text { Polish } \\
\text { Diet }\end{array}$} & \multicolumn{2}{|c|}{$\begin{array}{l}\text { Cereals and Cereal } \\
\text { Products in }\end{array}$} & \multirow{2}{*}{$\begin{array}{l}\text { Bread, Rolls } \\
\text { Bread } \\
\text { Products, \% }\end{array}$} & \multirow{2}{*}{$\begin{array}{c}\text { Flour, Bran, } \\
\text { Cooking } \\
\text { Ingredients, \% }\end{array}$} & \multirow{2}{*}{$\begin{array}{c}\text { Pizza, Pasta and } \\
\text { Other Flour } \\
\text { Dishes, } \%\end{array}$} & \multirow{2}{*}{$\begin{array}{l}\text { Fulfillment of } \\
\text { Reference } \\
\text { Values, \% }\end{array}$} \\
\hline & & $\mathrm{mg}$ or $\mu \mathrm{g}$ & $\%$ & & & & \\
\hline thiamin & $1.3 \mathrm{mg}$ & $0.4 \mathrm{mg}$ & 28.0 & 17.4 & 4.5 & & 31.9 \\
\hline niacin & $16.2 \mathrm{mg}$ & $3.1 \mathrm{mg}$ & 19.1 & 11.2 & 3.8 & & 20.7 \\
\hline riboflavin & $1.6 \mathrm{mg}$ & $0.3 \mathrm{mg}$ & 17.1 & 11.2 & 2.8 & & 23.1 \\
\hline vitamin D & $4.6 \mu \mathrm{g}$ & $0.3 \mu \mathrm{g}$ & 5.4 & 4.6 & & 0.8 & 1.5 \\
\hline vitamin A & $1194.6 \mu \mathrm{g}$ & $56.3 \mu \mathrm{g}$ & 4.7 & 3.2 & & 1.4 & 6.2 \\
\hline vitamin B12 & $4.5 \mu \mathrm{g}$ & $0.2 \mu \mathrm{g}$ & 3.4 & 1.8 & & 0.8 & 5.8 \\
\hline vitamin $C$ & $91.4 \mathrm{mg}$ & $1.4 \mathrm{mg}$ & 1.6 & (1) & & 0.8 & 1.5 \\
\hline
\end{tabular}

The table contains information only on two main sources of vitamins; empty places mean third and further positions of these sub-groups in the ranking; (1) pizza, pasta, and other flour dishes was the first contributor of vitamin C with $0.8 \%$ of supply.

\begin{tabular}{|c|c|c|c|c|}
\hline \multirow{2}{*}{$\begin{array}{l}\text { Nutrients } \\
\text { manganese }\end{array}$} & \multicolumn{2}{|c|}{$\begin{array}{c}\% \text { of Contribution from Cereals } \\
\text { and Cereal Products }\end{array}$} & \multicolumn{2}{|c|}{$\begin{array}{c}\% \text { of Contribution from Breads, } \\
\text { Rolls and Bread Products }\end{array}$} \\
\hline & 64.0 & & 48.6 & \\
\hline carbohydrates & 51.0 & & 36.3 & \\
\hline dietary fibre & 48.5 & & 35.4 & \\
\hline iron & 34.1 & & 24.9 & \\
\hline folate & 33.6 & & 20.7 & \\
\hline copper & 31.3 & & 22.1 & \\
\hline energy & 30.4 & & 21.9 & \\
\hline magnesium & 30.2 & & 21.0 & \\
\hline zinc & 28.6 & & 21.1 & \\
\hline thiamin & 28.0 & & 17.4 & \\
\hline phosphorus & 25.0 & & 17.6 & \\
\hline protein & 23.9 & & 16.5 & \\
\hline niacin & 19.1 & & 11.2 & \\
\hline sodium & 18.4 & & 17.5 & \\
\hline PUFA & 17.4 & & 13.6 & \\
\hline riboflavin & 17.1 & & 11.2 & \\
\hline potassium & 16.6 & & 12.2 & \\
\hline vitamin B6 & 15.5 & & 8.4 & \\
\hline vitamin E & 15.5 & & 12.3 & \\
\hline calcium & 12.0 & & 8.8 & \\
\hline fat & 9.9 & & 8.1 & \\
\hline MUFA & 9.1 & & 7.7 & \\
\hline SFA & 8.2 & & 6.9 & \\
\hline iodine & 6.6 & & 5.6 & \\
\hline cholesterol & 6,4 & & 4.2 & \\
\hline vitamin D & 5.4 & & 4.6 & \\
\hline vitamin A & 4.7 & & 3.2 & \\
\hline vitamin B12 & 3.4 & & 1.8 & \\
\hline vitamin $C$ & 1.6 & 1 & 0.3 & \\
\hline
\end{tabular}

Figure 2. Contribution of energy and nutrients in the average Polish diet from the category of cereals and cereal products and from breads, rolls, and bread products. 
Table 7. Rankings ${ }^{1 /}$ of main cereal groups as contributors of energy and nutrients ${ }^{2 /}$ in the average Polish diet.

\begin{tabular}{|c|c|c|c|c|c|c|c|c|c|c|c|c|c|c|c|c|c|c|c|c|c|c|c|c|c|c|c|c|c|}
\hline Food Group & 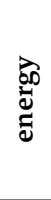 & 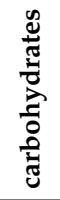 & 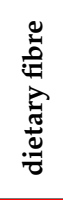 & 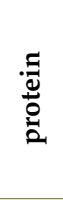 & 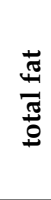 & 㞼 & 这 & 通 & 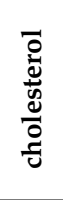 & 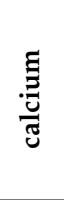 & 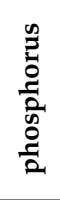 & 竞 & 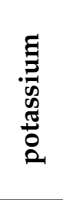 & 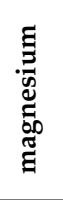 & .ี & : & 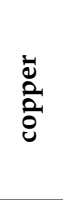 & 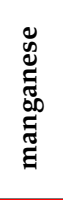 & $\stackrel{\mathscr{\Xi}}{\Xi}$ & 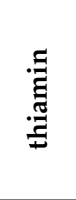 & 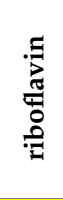 & $\stackrel{\Xi}{\overparen{\Xi}}$ & 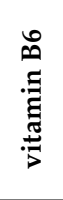 & 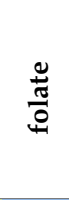 & 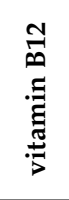 & 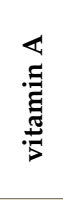 & 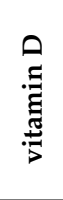 & 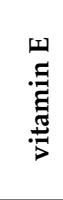 & 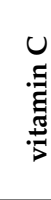 \\
\hline $\begin{array}{c}\text { bread, rolls, } \\
\text { bread products }\end{array}$ & 1 & 1 & 1 & 1 & 1 & 1 & 1 & 1 & 1 & 1 & 1 & 1 & 1 & 1 & 1 & 1 & 1 & 1 & 1 & 1 & 1 & 1 & 1 & 1 & 1 & 1 & 1 & 1 & 3 \\
\hline $\begin{array}{l}\text { flour, bran, } \\
\text { cooking } \\
\text { ingredients }\end{array}$ & 2 & 2 & 2 & 2 & 3 & 3 & 4 & 2 & & 3 & 2 & 5 & 3 & 4 & 2 & 2 & 2 & 4 & 5 & 2 & 2 & 2 & 2 & 2 & 3 & & & 3 & \\
\hline $\begin{array}{l}\text { pizza, pasta and } \\
\text { other flour dishes }\end{array}$ & 3 & 3 & 5 & 3 & 2 & 2 & 2 & 3 & 2 & 2 & 3 & 3 & 2 & 5 & 4 & 3 & 4 & 5 & 2 & 5 & 3 & 5 & 5 & 3 & 2 & 2 & 2 & 2 & 1 \\
\hline $\begin{array}{c}\text { ready-to-eat } \\
\text { cereal }\end{array}$ & 5 & 5 & 3 & 5 & 4 & 4 & 3 & 4 & & 4 & 5 & 2 & 5 & 3 & 3 & 5 & 5 & 3 & 3 & 4 & 4 & 3 & 4 & 4 & 4 & 3 & & 4 & 2 \\
\hline $\begin{array}{l}\text { rice, cooked } \\
\text { grains }\end{array}$ & 4 & 4 & 4 & 4 & 5 & 5 & 5 & 5 & & 5 & 4 & 4 & 4 & 2 & 5 & 4 & 3 & 2 & 4 & 3 & 5 & 4 & 3 & 5 & & & & 5 & \\
\hline
\end{tabular}

${ }^{1 /}$ the numbers for each nutrient denote the place of a given cereal main group in the ranking according to its contribution (\%) to a given nutrient intake; ${ }^{2 /}$ percentage of energy and

\begin{tabular}{|l|l|} 
& $>30 \%$ \\
& $20-30 \%$ \\
\cline { 2 - 2 } & $10-20 \%$ \\
& $5-10 \%$ \\
& $2.5-5 \%$ \\
& $<2.5 \%$ \\
\hline
\end{tabular}




\subsection{Cereals and Cereal Products as Sources of Energy}

Cereals and cereal products provided $30.4 \%$ of energy supply in the average Polish diet (i.e., 687 of $2261 \mathrm{kcal} /$ day). This means fulfilling of reference value for energy at $27.7 \%$. Table 3 shows that bread, rolls and other bread products were by far the largest contributor among the main cereal food groups. Second and third place in the daily supply of energy from cereals were took flour, bran, cooking ingredients and then pizza, pasta and other flour dishes respectively. The top three sub-groups were: bread and rolls $(16.4 \%)$, quick breads and other bread products $(5.5 \%)$, and wheat flour $(3.3 \%)$ (Table S2).

\subsection{Cereals and Cereal Products as Sources of Carbohydrates, Dietary Fibre, Protein, Total Fats, Fatty Acids, and Cholesterol}

As can be seen in Table 4, cereals and cereal products provided approximately half the average supply of carbohydrates and dietary fibre, one fourth of the protein and one sixth of the polyunsaturated fatty acids, while less than one tenth of the saturated and monounsaturated fatty acids and cholesterol came from the cereal category. The highest level of fulfilling the reference values was observed for carbohydrates, and then for dietary fibre and protein. Bread, rolls and other bread products were the top contributors, while the two next ranked main groups supplied considerably less. Among the sub-groups, bread and rolls, as well as quick breads and other bread products were the top sources of carbohydrates, protein and poly-unsaturated fatty acids as shown in the Supplementary Tables S3-S10.

\subsection{Cereals and Cereal Products as Sources of Minerals}

The largest share of cereals and cereal products in the supply of minerals was recorded in the case of manganese (over 60\%), followed by iron and copper (Table 5). For zinc and phosphorus, the share of cereals and cereal products amounted to $20-30 \%$, while for sodium, potassium and calcium this was $10-20 \%$. The highest supply compared to the reference values was observed for manganese and sodium. For phosphorus, copper, iron, and zinc the reference values were reached at the level of $30-40 \%$. Bread, rolls and other bread products were ranked first among all analyzed product groups. The second and third positions included various product groups, and the details are presented in the annex in the Tables S11-S20.

\subsection{Cereals and Cereal Products as Sources of Vitamins}

As shown in Table 6, cereals and cereal products provided one third of the total supply of folic acid. A significant share of $28 \%$ was recorded for thiamine. For other B vitamins (niacin, riboflavin, vitamin B6) and for vitamin E, cereals and cereal products contributed $15-20 \%$ of average daily supply. In the case of vitamins A, D, C and B12, cereals and cereal products were rather unimportant sources of them, providing up to $5 \%$ of the average daily intake. The highest fulfillment of the reference values was observed for thiamin (above 30\%), then for folate, niacin, riboflavin, vitamin B6, and E (20-30\%). The reference value for other vitamins was covered below $10 \%$. For most of the analyzed vitamins, the sub-groups containing bread, rolls and bread products were the main food source, with the highest proportion of folate. The second sub-group was flour, bran, and cooking ingredients for folate, thiamin, niacin, riboflavin and vitamin B6, as well as pizza, pasta and other flour dishes for vitamins: E, A, D, B12, and C. Detailed information about the sources of all nutrients are presented in Supplemental Tables S21-S30.

\subsection{Result Summary}

In conclusion, our results emphasize the importance of cereals and cereal products in providing nutrients at a higher level than energy for manganese, carbohydrates, dietary fibre, iron, folate, and copper (Figure 2). The main group from cereal category with the largest share in the supply of almost 
all of the analyzed nutrients and energy turned out to be bread, rolls, and bread products (Figure 2, Table 7).

\section{Discussion}

Cereals and cereal products form a significant part of the diet in Poland as contributors of energy and many nutrients. Our findings based on the 2016 HBS indicated that this food category contributed $687 \mathrm{kcal}$, which means $30.4 \%$ of total energy supply in the average Polish diet and almost $28 \%$ in comparison to the energy reference value for the Polish population. Cereals contribution to dietary energy intake is widely diversified between regions and countries. In developing Asian countries with rice-based diets, cereals contribute as much as $70-80 \%$ of energy intake; while, in high income countries with predominantly livestock-based diets cereals provide only $20-30 \%$ of total dietary calories [70]. In Europe, the share of cereals and cereal products in terms of energy contribution to the average diet amounts to $40 \%$ [71]. The structure of the average Polish diet reflects the second stage of the nutrition transition process, which is revealed in changing dietary patterns and lifestyle. This is the effect of transformation processes that started in Poland at the beginning of the 1990s and resulted in dynamic changes in the food market, evolving consumption patterns and social inequalities. According to the yearly CSO aggregated results of the Polish household budget surveys, the consumption of cereals and cereal products decreased by $23.6 \%$ during the last 10 years [54,72].

Findings from our research related to the importance of main groups and sub-groups within cereal category were compared to data from surveys conducted among American [6-8,66], British [73,74], Spanish [75], Japanese [10] and the Canary Islands' [9] population. In the average Polish diet, the highest share of energy contribution was related to bread, rolls and bread products (21.9\%). In the American population, the highest ranked food products were yeast breads and rolls (7.2\%); and cakes, cookies, quick bread, pastry and pies (7.2\%) [66]. In the UK diet, where cereals and cereal products contributed $34.5 \%$ of total energy supply, bread also was the main source of energy, however contributing almost two times less than in Poland (11.8\%) with a predominant share of white bread (7.3\%) [74].

Differences in the shares of particular cereal products in providing energy to the average Polish, US and UK diets $[6-8,66,73,74]$ result from the different consumption structure of this food category. In Poland, the consumption of bread and rolls, despite the declining tendency is at a higher level [76] compared to other countries [77,78]. Data from the CSO surveys in Poland indicate that in 1998 monthly consumption of bread amounted to $7.5 \mathrm{~kg}$ per person in a household, while in 2007 reached only $5.3 \mathrm{~kg}$ [79,80], $3.9 \mathrm{~kg}$ in 2014 [69], $3.5 \mathrm{~kg}$ in 2016 and $3.3 \mathrm{~kg}$ in 2017 [81]. It means that, during the last 20 years, the consumption of bread in Poland decreased by $56 \%$. The decline in bread consumption is the result of an increase in average income and standard of living improvements. It is known in the economics of consumption that staple food consumption, e.g., bread, is characterized by a negative income elasticity of demand [79]. A decrease in bread consumption is related to overall changes in eating patterns in Poland as well as an increase in the supply and consumption of bread substitutes and convenience cereal products, including ready-to-eat cereals, fast foods [20] and quick breads [79]. At the same time, the decision-making process of bread purchasing is determined by sensory $[20,82,83]$, health and nutrition attributes [20,82-88].

Of the analyzed macronutrients, cereals and cereal products are important sources of carbohydrates, dietary fibre and protein. In 2016, they delivered almost $140 \mathrm{~g}$ of carbohydrates, giving more than half of total daily intake and more than $100 \%$ as compared to the reference value. When considering main groups, bread, rolls, and bread products delivered $36.3 \%$ of carbohydrate supply. Findings for carbohydrate contribution to the American diet indicated in the first place yeast breads and rolls (10.9\%), followed by cakes, cookies, quick bread, pastry, and pie (8.9\%) [66]. Data for the British population showed that bread contributed $18 \%$ of carbohydrate intake (total percentage of this macronutrient from cereal category was $47 \%$ ) with the highest share related to white bread $(11.2 \%)[74]$. 
Dietary fibre contribution to the average Polish diet from cereals and cereal products amounted to $8.5 \mathrm{~g}$ (almost $50 \%$ of total daily supply), which means covering the reference value at approx. $36 \%$. Our findings indicated decreasing tendency in lower dietary fibre consumption considering the results of previous studies, which have shown the consumption of $24 \mathrm{~g}$ per person per day in 1996-2005 [89], and of $28 \mathrm{~g}$ in 2000-2009 [90]. Moreover the role of cereals and cereal products in dietary fibre supplying is diminished, as earlier these food categories contributed 12.1 and $11.6 \mathrm{~g}$ of dietary fibre, respectively. This fact should be considered unfavorable from the nutritional and health points of view due to the importance of dietary fibre in reducing risk and prevention of many diseases (as presented in the introduction) $[3,28,30,33,35,38,43,48]$. According to the WHO/FAO's population nutrient intake goals the dietary fibre intake should exceed $25 \mathrm{~g}$ per day [4]. The results of the current meta-analysis demonstrated that the beneficial reduction of DRNCDs risk is associated with daily intake of dietary fibre between $25 \mathrm{~g}$ and $29 \mathrm{~g}$ [23]. The Scientific Advisory Committee on Nutrition (SACN) in UK recommends even higher intake of $30 \mathrm{~g}$ of dietary fibre per day for adults, while current intake in this population group reached barely $18 \mathrm{~g}$ per day. In UK, cereals and cereal products contributed close to $42 \%$ of this amount, and $19 \%$ was contributed by bread [74].

In the average Polish diet, cereals and cereal products contributed almost $24 \%$ of total protein supply ( $30 \%$ as compared to the reference value), with main contributors of bread and rolls $(13.2 \%)$. The protein contribution from cereals in the average UK diet was at the same level as in Poland $(25 \%)$, including white bread (6.5\%, i.e., twice less than in Poland) [74].

Among the analyzed minerals provided by cereals and cereal products special attention should be paid to manganese, iron, magnesium, zinc, and copper. Our findings indicated that cereals and cereal products contributed $2 \mathrm{mg}$ of manganese and this amount gives almost two thirds of the total intake of this mineral (64.1\%) and more than $100 \%$ of the fulfillment of the reference value. The main suppliers were bread, rolls, and bread products. Findings from the Canary Islands' research also highlighted the role of cereals in manganese supply. The results for this population indicated that cereals and bakery products provided $46.3 \%$ of manganese [9]. Different food consumption patterns observed in the Japan population determine the structure of manganese contribution. According to the data from Japanese research, white rice was the main source of this micronutrient (24-33\% of the daily intake), while bread contributed less than 3\% [10]. It should be noted that only a small percentage of manganese from the diet is absorbed [91,92], as the presence of higher amounts of calcium, iron, phosphorus, phytates and fiber inhibits this process [91-94]. Therefore, the availability of manganese as well as other minerals from cereals and cereal products, especially whole grain, is limited, as they are partly bound in solid complexes with phytic acids and fiber [11,95]. In the face of these limitations, cereals and cereal products cannot solely provide the reference value for manganese in the Polish diet, as it is shown in the study. The other sources of this mineral are vegetables, potatoes, fruit and tea $[64,96]$. Especially very common in Poland habitual drinking of tea infusions may significantly contribute to the meeting of the reference value for manganese [97-99]. However, manganese is an essential nutrient due to its role $[10,12-15]$ in terms of the metabolism of carbohydrates, amino acids, and cholesterol $[10,16,17]$ as well as many functions of different systems [14-16].

With respect to iron, magnesium, zinc, and copper, cereals and cereal products provided a similar percentage $(28-34 \%)$ of these micronutrients as it was stated for energy contribution. However, their share in meeting of the reference values was more diversified and amounted to $24-40 \%$. The most important main group in delivering these micronutrients was bread, rolls, and bread products with special attention given to bread and rolls. Findings from the American surveys indicated that ready-to-eat-cereals were the most important food group from the cereal category in contribution of iron (15-19\% of total supply) and zinc (approx. $4 \%$ ) $[8,66]$. In the average Japanese diet, rice turned out to be the first group in terms of supplying copper (23-30\%) and zinc (20-25\%) [10]. According to a Spanish study, cereal and grain products were the food groups with the highest contribution to total iron intake (approx. 27\%) [100]. Findings from the Canary Islands' research noted that cereals 
contributed $19-21 \%$ of iron, copper and zinc to the average diets, while the share of bakery products related to these micronutrients contribution was significantly lower [9].

The data regarding the British population indicated a similar share of cereal category in supply of magnesium and zinc as in Poland (30 and 27\%, respectively). Analogically to Poland, bread was the main source of these minerals in diet. It is worth noting that significant differences occurred in the supply of iron. In British population, on average, cereals provided almost $47 \%$ of this nutrient, and breakfast cereals ('high fibre breakfast cereals' and 'other breakfast cereals') was the major iron contributor to the diet (17\%), which affected this discrepancy [74].

Differences in the importance of particular cereal product groups in providing these four minerals in the compared countries are the consequences of different dietary habits and consumption patterns. In the US about $16 \%$ of the population consumes ready-to-eat-cereals that are fortified with many nutrients and the consumers of these convenience cereal products had higher intake of shortfall nutrients [101] and more favorable nutrient intake profiles [102]. Moreover, the consumption of ready-to-eat-cereals was associated with higher quality and healthier diets [101,103]. This can explain the importance of ready-to-eat-cereals in providing iron in the average American diet. In Poland, fortified ready-to-eat-cereals are targeted at children and teenagers, while other population groups consume predominantly natural cereal flakes.

The role of zinc and iron should be emphasized when considering the nutritional value of vegetarian diets. Elimination of meat and meat products as a valuable source of macro- and micronutrients, particularly iron and zinc of high bioavailability [104-107] leads to lower absorption of these nutrients from vegetarian than from non-vegetarian diets [12,104,108,109]. It should be underlined that iron is required for many metabolic processes in the human body. Its deficiency is widely analyzed in the scientific literature [10,100,110-114]. The role of zinc is related to its structural role in proteins and cell membranes, and regulatory role in gene expression [10]. As far as copper is concerned, plant food is a good contributor of this micronutrient and vegetarian diets provide greater share of copper than non-vegetarian diets [12]. Copper is involved in energy and iron metabolism, and neurotransmitter synthesis and metabolism $[10,17]$ as it is a nutrient protecting the human body against oxidative stress [13].

Phosphorus, sodium, potassium, and calcium were delivered by cereals and cereal products in a relatively low percentage (12-15\%). The detailed data indicated that bread, rolls, and bread products were the main cereal products in contribution of these micronutrients. It is worth noting the unfavorable role of bread in supplying of sodium to the diet (18\% of total sodium intake, which means half of the reference value). In case of the British population, the data is more unfavorable as cereal food category contributes $33 \%$ of sodium intake, including $17 \%$ from bread [74]. The addition of salt is of technological importance in the process of baking bread, but in developed countries excessive sodium intake is the main risk of hypertension [74]. According to the American survey, findings indicated lower contribution of phosphorus by yeast breads and rolls (4.5\%); cakes, cookies, quick breads, pastry and pie (3.6\%); and ready-to-eat cereals (2.3\%) [66].

Cereals and cereal products are an important source of thiamin, folate, and in a smaller proportion of riboflavin, niacin, vitamins B6 and E. For folate, cereals and cereal products provided almost 34\% of total supply (24\% in comparison to the reference value). Many research showed shortages of folate in different population groups in Poland, and vegetables and grains were the main sources of this vitamin [115]. This is particularly important due to the function of this vitamin in the human body, especially in lowering the risk of NTDs (neural tube defects) [116]. In terms of the folate contribution, our findings indicated that the main food group was bread, rolls, and bread products (20.7\%). Findings from the American research identified two main sources of folate: ready-to-eat cereals (18.7\%), and yeast breads and rolls (16.6\%) [66]. The main contributors of folate in the total diet of US adults $\geq 51$ years old were ready-to-eat cereals (21.0\%), and breads, rolls, and tortillas (13.4\%) [8]. Again, the differences which occurred between Polish and US populations reflect diverse dietary habits in the 
case of ready-to-eat cereals consumption in combination with various approaches to food fortification in the public health policy.

Thiamin was delivered by cereals and cereal products in a similar percentage compared to the share of this food in dietary energy contribution. Our findings indicated the bread, rolls, and bread products $(17.4 \%)$ as main contributors of thiamin. Data from the Spanish study indicated that cereals and grains contributed thiamin at a higher level (23.9\%) [75]. In the American diet, the following food groups originating from cereals were identified in case of thiamin: yeast breads and rolls $(14.7 \%)$, and ready-to-eat cereal (9.9\%) [66].

This study has thoroughly documented the importance of cereals and cereal products in the Polish diet. Having in mind the urgent challenge to shift our diet to a more sustainable one, the Polish consumers should eat more whole grain foods to obtain more health benefits from the cereal category. The current dietary guidelines for the Polish population (the Pyramid of Healthy Eating and Physical Activity, updated in 2018) emphasize this recommendation as cereals and cereal products were placed at the second stage of the pyramid (after vegetables and fruit) and the accompanying tip encourage people to 'eat cereal products, especially whole grains' [117]. While dietary guidelines remain primarily health focused, synergies between health and sustainability mean that the guidelines include implicit sustainability messaging [118]. However, in many countries dietary guidelines were already updated and they combine tips regarding healthy food choices and the rules directly focusing on environmental or social aspects of sustainability.

The 2016 HBS sample size, consistent approach to classifying food products, and the use of the HBS methodology to record purchased and consumed food in terms of quantity and value are strengths of the presented study. Surveys of households are conducted using a representative method based on a random sample, which gives the opportunity to generalize the obtained results for all households in the country. The HBS analyzes consumption on a monthly basis; each household participates in the recording of purchased and consumed food for one month. However, there are some limitations, particularly the reliance on self-recording of information on consumption in a diary, which can lead to an under- and/or overestimation of consumption data, even though HBS uses well-established procedures to control all recordings. Additionally, the current edition of "Nutritive Value Tables for Foods and Meals" (4th ed., 2017) includes new products and technological modifications, which may cause difficulties in the comparison of current results to data from earlier years. It should be noted that, in the CSO budget survey, households record the amount of all food obtained for the household, i.e., which was purchased, comes from self-supply or was received as a gift. The moment of consumption of food products is the moment of their acquisition by a household. In the case of non-response of households, the methods of a random replacement of households and sequential sampling are applied. The method of conducting a household budget survey also constitutes a difficulty in comparing with other studies on food sources of energy and nutrients. However, these limitations of survey methods are common and typical. Nevertheless, household budget surveys are the only representative method of data collection regarding food consumption and other living conditions of the Polish population.

\section{Conclusions}

In conclusion, this study indicated that cereals and cereal products are important sources of energy and nutrients in the average Polish diet. The highest levels of contribution (above 30\%) were observed for manganese, carbohydrates, dietary fibre, iron, folate, and copper. Cereals and cereal products provided $20-30 \%$ of the average intake of protein, thiamin, phosphorus and zinc, and $10-20 \%$ of the average supply of PUFA, sodium, potassium, calcium, riboflavin, niacin, and vitamin B6. Cereals and cereal products remain staple foods for the Polish population, as can be seen in the high contribution levels of these products to energy, carbohydrates, protein and some micronutrients. Our results document the importance of cereals and cereal products in the Polish diet from the nutritional and heath points of view. 
Supplementary Materials: The following are available online at http:/ /www.mdpi.com/2072-6643/11/3/679/s1 in Supplemental Section: Table S1. Food grouping for the purpose of the nutrient source analysis; Table S2. Food sources of energy contribution from cereals and cereal products in the average Polish diet; Table S3. Food sources of carbohydrates contribution from cereals and cereal products in the average Polish diet; Table S4. Food sources of protein contribution from cereals and cereal products in the average Polish diet; Table S5. Food sources of total fat contribution from cereals and cereal products in the average Polish diet; Table S6. Food sources of SFA contribution from cereals and cereal products in the average Polish diet; Table S7. Food sources of MUFA contribution from cereals and cereal products in the average Polish diet; Table S8. Food sources of PUFA contribution from cereals and cereal products in the average Polish diet; Table S9. Food sources of cholesterol contribution from cereals and cereal products in the average Polish diet; Table S10. Food sources of dietary fibre contribution from cereals and cereal products in the average Polish diet; Table S11. Food sources of calcium contribution from cereals and cereal products in the average Polish diet; Table S12. Food sources of phosphorus contribution from cereals and cereal products in the average Polish diet; Table S13. Food sources of sodium contribution from cereals and cereal products in the average Polish diet; Table S14. Food sources of potassium contribution from cereals and cereal products in the average Polish diet; Table S15. Food sources of magnesium contribution from cereals and cereal products in the average Polish diet; Table S16. Food sources of iron contribution from cereals and cereal products in the average Polish diet; Table S17. Food sources of zinc contribution from cereals and cereal products in the average Polish diet; Table S18. Food sources of copper contribution from cereals and cereal products in the average Polish diet; Table S19. Food sources of manganese contribution from cereals and cereal products in the average Polish diet; Table S20. Food sources of iodine contribution from cereals and cereal products in the average Polish diet; Table S21. Food sources of thiamin contribution from cereals and cereal products in the average Polish diet; Table S22. Food sources of riboflavin contribution from cereals and cereal products in the average Polish diet; Table S23. Food sources of niacin contribution from cereals and cereal products in the average Polish diet; Table S24. Food sources of vitamin B6 contribution from cereals and cereal products in the average Polish diet; Table S25. Food sources of folate contribution from cereals and cereal products in the average Polish diet; Table S26. Food sources of vitamin B12 contribution from cereals and cereal products in the average Polish diet; Table S27. Food sources of vitamin A contribution from cereals and cereal products in the average Polish diet; Table S28. Food sources of vitamin D contribution from cereals and cereal products in the average Polish diet; Table S29. Food sources of vitamin E contribution from cereals and cereal products in the average Polish diet; Table S30. Food sources of vitamin C contribution from cereals and cereal products in the average Polish diet.

Author Contributions: W.L. conducted calculations from the primary database of the 2016 HBS using the R environment; H.G.-W. contributed to article design, food grouping, statement of ranking; data analysis, discussion, and part of the introduction, K.R. was involved in the introduction and discussion, M.C. contributed to analysis, and J.Z. was involved in data description. All authors participated in conclusions, read and approved the final manuscript.

Funding: The publication was financed by Polish Ministry of Science and Higher Education within funds of Faculty of Human Nutrition and Consumer Sciences, Warsaw University of Life Sciences (WULS), for scientific research.

Acknowledgments: The authors are grateful to the Central Statistical Office in Warsaw; the analysis was conducted based on the primary data of the 2016 Household Budget Survey.

Conflicts of Interest: The authors declare no conflict of interest.

\section{References}

1. McKevith, B. Nutritional aspects of cereals. Br. Nutr. Found. Nutr. Bull. 2004, 29, 111-142. [CrossRef]

2. Kushi, L.H.; Meyer, K.A.; Jacobs, D.R. Cereals, legumes, and chronic disease risk reduction: evidence from epidemiologic studies. Am. J. Clin. Nutr. 1999, 70, 451s-458s. [CrossRef]

3. McIntosh, G.H. Cereal foods, fibres and the prevenation of cancers. Aust. J. Nutr. Diet. 2001, 58, S35-S48.

4. World Health Organization. Diet, Nutrition and the Prevention of Chronic Diseases; WHO: Genewa, Switzerland, 2003; ISSN 0512-3054.

5. FAO Cereal Supply and Demand Brief. World Food Situation. Cereal production and inventories to decline but overall supplies remain adequate. Food and Agriculture Organization of the United Nations. Available online: http:/ / www.fao.org/worldfoodsituation/csdb/en/ (accessed on 29 January 2019).

6. Papanikolaou, Y.; Fulgoni, V.L. Certain grain foods can be meaningful contributors to nutrient density in the diets of U.S. children and adolescents: Data from the national health and nutrition examination survey, 2009-2012. Nutrients 2017, 9. [CrossRef] [PubMed]

7. O’Neil, C.E.; Nicklas, T.A.; Zanovec, M.; Cho, S. Whole-Grain Consumption Is Associated with Diet Quality and Nutrient Intake in Adults: The National Health and Nutrition Examination Survey, 1999-2004. J. Am. Diet Assoc. 2010, 110, 1461-1468. [CrossRef] [PubMed] 
8. Papanikolaou, Y.; Fulgoni, V. Grains Contribute Shortfall Nutrients and Nutrient Density to Older US Adults: Data from the National Health and Nutrition Examination Survey, 2011-2014. Nutrients 2018, 10, 534. [CrossRef]

9. Rubio, C.; Gutiérrez, Á.J.; Revert, C.; Reguera, J.I.; Burgos, A.; Hardisson, A. Daily dietary intake of iron, copper, zinc and manganese in a Spanish population. Int. J. Food Sci. Nutr. 2009, 60, 590-600. [CrossRef]

10. Yamada, M.; Asakura, K.; Sasaki, S.; Hirota, N.; Notsu, A.; Todoriki, H.; Miura, A.; Fukui, M.; Date, C. Estimation of intakes of copper, zinc, and manganese in Japanese adults using 16-day semi-weighed diet records. Asia Pac. J. Clin. Nutr. 2014, 23, 465-472. [CrossRef]

11. Schlemmer, U.; Frølich, W.; Prieto, R.M.; Grases, F. Phytate in foods and significance for humans: Food sources, intake, processing, bioavailability, protective role and analysis. Mol. Nutr. Food Res. 2009, 53, S330-S375. [CrossRef]

12. Hunt, J.R. Biaoavailability of iron, zinc, and other trace minerals from vegetarian diets. Am. J. Clin. Nutr. 2003, 78, 633S-639S. [CrossRef]

13. Sánchez, C.; López-Jurado, M.; Aranda, P.; Llopis, J. Plasma levels of copper, manganese and selenium in an adult population in southern Spain: Influence of age, obesity and lifestyle factors. Sci. Total Environ. 2010, 408, 1014-1020. [CrossRef]

14. Avila, D.S.; Puntel, R.L.; Aschner, M. Manganese in Health and Disease. In Interrelations between Essential Metal Ions and Human Diseases; Springer: Dordrecht, The Netherlands, 2013; pp. 199-227.

15. Chen, P.; Bornhorst, J.; Aschner, M. Manganese metabolism in humans. Front. Biosci. 2018, 23, 1655-1679. [CrossRef]

16. Watts, D.L. The nutritional relationships of manganese. J. Orthomol. Med. 1990, 5, 219-222. [CrossRef]

17. Soetan, K.O.; Olaiya, C.O.; Oyewole, O.E. The importance of mineral elements for humans, domestic animals and plants. African J. Food Sci. 2010, 4, 200-222. [CrossRef]

18. Bach Knudsen, K.E. Microbial Degradation of Whole-Grain Complex Carbohydrates and Impact on Short-Chain Fatty. Adv. Nutr. 2015, 206-213. [CrossRef] [PubMed]

19. Ludwig, D.S.; Hu, F.B.; Tappy, L.; Brand-Miller, J. Dietary carbohydrates: Role of quality and quantity in chronic disease. BMJ 2018, 361. [CrossRef]

20. Gellynck, X.; Kühne, B.; Van Bockstaele, F.; Van de Walle, D.; Dewettinck, K. Consumer perception of bread quality. Appetite 2009, 53, 16-23. [CrossRef]

21. Aune, D.; Keum, N.; Giovannucci, E.; Fadnes, L.T.; Boffetta, P.; Greenwood, D.C.; Tonstad, S.; Vatten, L.J.; Riboli, E.; Norat, T. Whole grain consumption and risk of cardiovascular disease, cancer, and all cause and cause specific mortality: systematic review and dose-response meta-analysis of prospective studies. BMJ 2016, 353, i2716. [CrossRef]

22. Mayor, S. Eating more fibre linked to reduced risk of non-communicable diseases and death, review finds. BMJ 2019, 364, 1159. [CrossRef]

23. Reynolds, A.; Mann, J.; Cummings, J.; Winter, N.; Mete, E.; Te Morenga, L. Carbohydrate quality and human health: A series of systematic reviews and meta-analyses. Lancet (London, England) 2019, 393, 434-445. [CrossRef]

24. Călinoiu, L.F.; Vodnar, D.C. Whole Grains and Phenolic Acids: A Review on Bioactivity, Functionality, Health Benefits and Bioavailability. Nutrients 2018, 10, 1615. [CrossRef]

25. Huang, T.; Xu, M.; Lee, A.; Cho, S.; Qi, L. Consumption of whole grains and cereal fiber and total and cause-specific mortality: prospective analysis of 367,442 individuals. BMC Biol. 2015, 13, 59. [CrossRef]

26. Kim, Y.; Je, Y. Dietary fiber intake and total mortality: A meta-analysis of prospective cohort studies. Am. J. Epidemiol. 2014, 180, 565-573. [CrossRef]

27. Zhou, X.; Xue, H.; Duan, R.; Liu, Y.; Zhang, L.; Harvey, L.; Cheng, G. The Cross-Sectional Association of Energy Intake and Dietary Energy Density with Body Composition of Children in Southwest China. Nutrients 2015, 7, 5396-5412. [CrossRef]

28. McRae, M.P. Dietary Fiber Is Beneficial for the Prevention of Cardiovascular Disease: An Umbrella Review of Meta-analyses. J. Chiropr. Med. 2017, 16, 289-299. [CrossRef]

29. Seal, C.J.; Brownlee, I.A. Whole-grain foods and chronic disease: evidence from epidemiological and intervention studies. Proc. Nutr. Soc. 2015, 74, 313-319. [CrossRef]

30. Gani, A.; Wani, S.; Masoodi, F.; Hammed, G. Whole-Grain Cereal Bioactive Compounds and Their Health Benefits: A Review. J. Food Process. Technol. 2012, 3, 1-10. [CrossRef] 
31. Tang, G.; Wang, D.; Long, J.; Yang, F.; Si, L. Meta-Analysis of the Association Between Whole Grain Intake and Coronary Heart Disease Risk. Am. J. Cardiol. 2015, 115, 625-629. [CrossRef]

32. Bechthold, A.; Boeing, H.; Schwedhelm, C.; Hoffmann, G.; Knüppel, S.; Iqbal, K.; De Henauw, S.; Michels, N.; Devleesschauwer, B.; Schlesinger, S.; et al. Food groups and risk of coronary heart disease, stroke and heart failure: A systematic review and dose-response meta-analysis of prospective studies. Crit. Rev. Food Sci. Nutr. 2017, 1-20. [CrossRef]

33. McRae, M.P. Health Benefits of Dietary Whole Grains: An Umbrella Review of Meta-analyses. J. Chiropr. Med. 2017, 16, 10-18. [CrossRef]

34. Chen, J.; Huang, Q.; Shi, W.; Yang, L.; Chen, J.; Lan, Q. Meta-Analysis of the Association Between Whole and Refined Grain Consumption and Stroke Risk Based on Prospective Cohort Studies. Asia Pacific J. Public Heal. 2016, 28, 563-575. [CrossRef] [PubMed]

35. De Munter, J.S.; Hu, F.B.; Spiegelman, D.; Franz, M.; van Dam, R.M. Whole Grain, Bran, and Germ Intake and Risk of Type 2 Diabetes: A Prospective Cohort Study and Systematic Review. PLoS Med. 2007, 4, e261. [CrossRef] [PubMed]

36. Ley, S.; Hamdy, O.; Mohan, V.; Hu, F.B. Prevention and Management of Type 2 Diabetes: Dietary Components and Nutritional Strategies. Lancet 2014, 383, 1999-2007. [CrossRef]

37. Sun, Q.; Spiegelman, D.; van Dam, R.M.; Holmes, M.D.; Malik, V.S.; Willett, W.C.; Hu, F.B. White Rice, Brown Rice, and Risk of Type 2 Diabetes in US Men and Women. Arch. Intern. Med. 2010, 170, 961-969. [CrossRef] [PubMed]

38. Schatzkin, A.; Park, Y.; Leitzmann, M.F.; Hollenbeck, A.R.; Cross, A.J. Prospective Study of Dietary Fiber, Whole Grain Foods, and Small Intestinal Cancer. Gastroenterology 2008, 135, 1163-1167. [CrossRef] [PubMed]

39. Kunzmann, A.T.; Coleman, H.G.; Huang, W.-Y.; Kitahara, C.M.; Cantwell, M.M.; Berndt, S.I. Dietary fiber intake and risk of colorectal cancer and incident and recurrent adenoma in the Prostate, Lung, Colorectal, and Ovarian Cancer Screening Trial. Am. J. Clin. Nutr. 2015, 102, 881-890. [CrossRef] [PubMed]

40. Chabowski, B.R.; Mena, J.A.; Gonzalez-Padron, T.L. The structure of sustainability research in marketing, 1958-2008: a basis for future research opportunities. J. Acad. Mark. Sci. 2011, 39, 55-70. [CrossRef]

41. Gonzalez, C.A.; Riboli, E. Diet and cancer prevention: Contributions from the European Prospective Investigation into Cancer and Nutrition (EPIC) study. Eur. J. Cancer 2010, 46, 2555-2562. [CrossRef]

42. McRae, M.P. The Benefits of Dietary Fiber Intake on Reducing the Risk of Cancer: An Umbrella Review of Meta-analyses. J. Chiropr. Med. 2018, 17, 90-96. [CrossRef]

43. Aune, D.; Chan, D.S.; Lau, R.; Vieira, R.; Greenwood, D.C.; Kampman, E.; Norat, T. Dietary fibre, whole grains, and risk of colorectal cancer: systematic review and dose-response meta-analysis of prospective studies. BMJ 2011, 343, d6617. [CrossRef]

44. Murphy, N.; Norat, T.; Ferrari, P.; Jenab, M.; Bueno-de-Mesquita, B.; Skeie, G.; Dahm, C.C.; Overvad, K.; Olsen, A.; Tjønneland, A.; et al. Dietary Fibre Intake and Risks of Cancers of the Colon and Rectum in the European Prospective Investigation into Cancer and Nutrition (EPIC). PLoS One 2012, 7, e39361. [CrossRef] [PubMed]

45. Baena, R.; Salinas, P. Diet and colorectal cancer. Maturitas 2015, 80, 258-264. [CrossRef] [PubMed]

46. Ben, Q.; Sun, Y.; Chai, R.; Qian, A.; Xu, B.; Yuan, Y. Dietary fiber intake reduces risk for colorectal adenoma: a meta-analysis. Gastroenterology 2014, 146, 689-699.e6. [CrossRef]

47. Song, Y.; Liu, M.; Yang, F.G.; Cui, L.H.; Lu, X.Y.; Chen, C. Dietary fibre and the risk of colorectal cancer: a case- control study. Asian Pac. J. Cancer Prev. 2015, 16, 3747-3752. [CrossRef] [PubMed]

48. Wiseman, M.; Thompson, R. Diet, Nutrition, Physical Activity and Cancer: A Global Perspective; World Cancer Research Fund and American Institute for Cancer Research: London, UK, 2018; ISBN 9781912259465.

49. Popkin, B. An overview on the nutrition transition and its health implications: the Bellagio meeting. Public Health Nutr. 2002, 5, 93-103. [CrossRef]

50. Smil, V. Feeding the World: A Challenge for the Twenty-First Century; MIT Press: Cambridge, MA, USA, 2000; ISBN 9780262194327.

51. Kearney, J. Food consumption trends and drivers. Philos. Trans. R. Soc. B Biol. Sci. 2010, 365, $2793-2807$. [CrossRef]

52. Drewnowski, A.; Popkin, B.M. The nutrition transition: new trends in the global diet. Nutr. Rev. 1997, 55, 31-43. [CrossRef] 
53. Willett, W.; Rockström, J.; Loken, B.; Springmann, M.; Lang, T.; Vermeulen, S.; Garnett, T.; Tilman, D.; DeClerck, F.; Wood, A.; et al. Food in the Anthropocene: the healthy diets from sustainable food systems. Summ. Rep. EAT-Lancet Comm. 2019, 393, 447-492. [CrossRef]

54. Central Statistical Office. Household Budget Survey in 2016; Central Statistical Office: Warsaw, Poland, 2017; ISBN 0208-9793.

55. Central Statistical Office. Methodology of Household Survey (in Polish); Barlik, M., Siwiak, K., Eds.; Central Statistical Office, Zakład Wydawnictw Statystycznych: Warsaw, Poland, 2011.

56. Laskowski, W.; Górska-Warsewicz, H.; Kulykovets, O. Meat, Meat Products and Seafood as Sources of Energy and Nutrients in the Average Polish Diet. Nutrients 2018, 10, 1412. [CrossRef]

57. Górska-Warsewicz, H.; Laskowski, W.; Kulykovets, O.; Kudlińska-Chylak, A.; Czeczotko, M.; Rejman, K. Food Products as Sources of Protein and Amino Acids-The Case of Poland. Nutrients 2018, 10, 1977. [CrossRef]

58. Laskowski, W.; Górska-Warsewicz, H. Nutrient Density of the Average Polish Diet. Economic Analysis, 1st ed.; Laskowski Publisher: Warsaw, Poland, 2014; ISBN 978-83-941257-1-4. (In Polish)

59. Kunachowicz, H.; Przygoda, B.; Nadolna, I.; Iwanow, K. Tabele Składu i Wartości Odżywczej Żywności, 4th ed.; PZWL Wydawnictwo Lekarskie: Warsaw, Poland, 2017; ISBN 9788320053111.

60. Fox, J.; Leanage, A. R and the Journal of Statistical Software. J. Stat. Softw. 2016, 73, 1-13. [CrossRef]

61. R Development Core Team R Language Definition. Available online: https://cran.r-project.org/doc/ manuals / r-release/R-lang.pdf (accessed on 1 August 2018).

62. Lang, M. Efficient $R$ Programming. J. Stat. Softw. 2017, 80. [CrossRef]

63. Rejman, K.; Kowrygo, B.; Laskowski, W. Evaluation of the Structure of Food Consumption in Poland in the Context of Demands of Sustainable Consumption (in Polish). J. Agribus. Rural Dev. 2015, 37, 503-512. [CrossRef]

64. Jarosz, M. Reference Energy and Nutrient Intake for the Polish Population (in Polish); Instytut Żywności i Żywienia: Warsaw, Poland, 2017; ISBN 9788386060894.

65. What We Eat in America. Available online: https://www.ars.usda.gov/ARSUserFiles/80400530/pdf/1314/ Food_categories_2013-2014.pdf (accessed on 13 August 2018).

66. O'Neil, C.E.; Keast, D.R.; Fulgoni, V.L.; Nicklas, T.A. Food sources of energy and nutrients among adults in the US: NHANES 2003-2006. Nutrients 2012, 4, 2097-2120. [CrossRef]

67. Scientific Report of the 2015 Dietary Guidelines Advisory Committee Appendix E-2.7: Major Categories and Subcategories used in DGAC Analyses of WWEIA Food Categories Part E. Section 2: Supplementary Documentation to the 2015 DGAC Report Scie. Available online: https: / /health.gov / dietaryguidelines/ DGAC-Major-categories-and-subcategories-from-WWEIA-FoodCategories.pdf (accessed on 13 August 2018).

68. Rhodes, D.G.; Adler, M.E.; Clemens, J.C.; Moshfegh, A.J. What we eat in America food categories and changes between survey cycles. J. Food Compos. Anal. 2017, 64, 107-111. [CrossRef]

69. Górska-Warsewicz, H.; Świątkowska, M. Consumption of Bread and other Cereals Products in the Polish Households. In Innovative Cereal Products for the Consumer Perspective (in Polish); Jeżewska-Zychowicz, M., Ed.; Warsaw University of Life Sciences: Warsaw, Poland, 2015; pp. 7-35.

70. Alexandratos, N.; Bruinsma, J. Worlds Agriculture Towards 2030/2050: the 2012 Revision. Working Paper No. 12.03; FAO: Rome Italy, 2012.

71. Nagyová, L'.; Rovný, P.; Stávková, J.; Uličná, M.; Mad'arová, L'. Consumer perception of bread quality. Acta Univ. Agric. Silvic. Mendelianae Brun. 2009, 57, 115-122. [CrossRef]

72. Central Statistical Office. Household Budget Survey in 2013; Central Statistical Office: Warsaw, Poland, 2013; ISBN 0208-9793.

73. Steer, T.; Thane, C.; Stephen, A.; Jebb, S. Bread in the diet: consumption and contribution to nutrient intakes of British adults. Proc. Nutr. Soc. 2008, 67, E363. [CrossRef]

74. Roberts, C.; Steer, T.; Maplethorpe, N.; Cox, L.; Meadows, S.; Nicholson, S.; Page, P.; Swan, G. National Diet and Nutrition Survey: Results from Years 7 and 8 (combined) of the Rolling Programme (2014/2015 to 2015/2016) Public Health England. 2018. Available online: https:/ / assets.publishing.service.gov.uk/government/uploads/system/uploads/attachment_data/ file/699241/NDNS_results_years_7_and_8.pdf (accessed on 6 March 2019). [CrossRef] 
75. Mielgo-Ayuso, J.; Aparicio-Ugarriza, R.; Olza, J.; Aranceta-Bartrina, J.; Gil, Á.; Ortega, R.; Serra-Majem, L.; Varela-Moreiras, G.; González-Gross, M. Dietary Intake and Food Sources of Niacin, Riboflavin, Thiamin and Vitamin B6 in a Representative Sample of the Spanish Population. The Anthropometry, Intake, and Energy Balance in Spain (ANIBES) Study t. Nutrients 2018, 10, 846. [CrossRef]

76. Piwowar, A. Consumption of Basic Products of Vegetable and Animal Origin in Poland in 2000-2012 (in Polish). Handel Wewnętrzny 2017, 1, 94-103.

77. Sandvik, P.; Kihlberg, I.; Lindroos, A.K.; Marklinder, I.; Nydahl, M. Bread consumption patterns in a Swedish national dietary survey focusing particularly on whole-grain and rye bread. Food Nutr. Res. 2014, 58, 1-11. [CrossRef]

78. Goryńska-Goldman, E. Tendencies of bread consumption in Poland (in Polish). Sci. Pol. Oeconomica 2010, 9 , 73-86.

79. Borowska, A.; Rejman, K. The Use of Nutrition and Health Information on the Bakery Market to Increase the Demand for its Products (in Polish). Med. Sport. Pract. 2009, 10, $79-87$.

80. Borowska, A.; Rejman, K. Bread Consumption and Consumer Preferences Considering Product Innovation of Bakery Sector (in Polish). Stud. i Mater. Zarzadzania Wiedza 2011, 52, 309-322.

81. Central Statistical Office. Statistical Yearbook of the Republic of Poland; Central Statistical Office: Warsaw, Poland, 2018.

82. Heiniö, R.L.; Noort, M.W.J.; Katina, K.; Alam, S.A.; Sozer, N.; de Kock, H.L.; Hersleth, M.; Poutanen, K. Sensory characteristics of wholegrain and bran-rich cereal foods-A review. Trends Food Sci. Technol. 2016, 47, 25-38. [CrossRef]

83. Heenan, S.P.; Dufour, J.-P.; Hamid, N.; Harvey, W.; Delahunty, C.M. The sensory quality of fresh bread: Descriptive attributes and consumer perceptions. Food Res. Int. 2008, 41, 989-997. [CrossRef]

84. Heenan, S.P.; Hamid, N.; Dufour, J.-P.; Harvey, W.; Delahunty, C.M. Consumer freshness perceptions of breads, biscuits and cakes. Food Qual. Prefer. 2009, 20, 380-390. [CrossRef]

85. Heenan, S.P.; Dufour, J.-P.; Hamid, N.; Harvey, W.; Delahunty, C.M. Characterisation of fresh bread flavour: Relationships between sensory characteristics and volatile composition. Food Chem. 2009, 116, 249-257. [CrossRef]

86. Bernstein, A.J.; Rose, D.J. Preference Mapping of Commercial Whole Wheat Breads. Cereal Chem. J. 2015, 92, 278-283. [CrossRef]

87. Ha, C.-H.; Lee, S.M.; Lee, E.-K.; Kim, K.-O. Effect of flour information (origin and organic) and consumer attitude to health and natural product on bread acceptability of Korean consumers. J. Sens. Stud. 2017, 32, e12281. [CrossRef]

88. Pasiakos, S.M.; Agarwal, S.; Lieberman, H.R.; Fulgoni, V.L. Sources and amounts of animal, dairy, and plant protein intake of US adults in 2007-2010. Nutrients 2015, 7, 7058-7069. [CrossRef] [PubMed]

89. Hamułka, J.; Wawrzyniak, A.; Sosińska, S. Evaluation of Dietary Fibre, Soluble and Insoluble Fibre Food Intake in Polish Households in 1996-2005 (in Polish). Rocz. Państwowego Zakładu Hig. 2008, 59, 211-221.

90. Górecka, D.; Janus, P.; Borysiak-Marzec, P.; Dziedzic, K. Analysis of Consumption of Dietary Fibre and its Fractions in Poland in Last Decade based on the Statistical Yearbook Data (in Polish). Probl Hig Epidemio 2011, 92, 705-708.

91. Dietary Reference Intakes for Vitamin A, Vitamin K, Arsenic, Boron, Chromium, Copper, Iodine, Iron, Manganese, Molybdenum, Nickel, Silicon, Vanadium, and Zinc; Chapter 10: Manganese; Institute of Medicine, National Academies Press (US): Washington, DC, USA, 2001; ISBN 0309072794. [CrossRef]

92. Brzozowska, A. Microminerals. In Human Nutrition. Th Base of Nutrition (in Polish); Gawęcki, J., Ed.; Wydawnictwo Naukowe PWN: Warsaw, Poland, 2010; pp. 228-239. ISBN 9788301163204.

93. Lonnerdal, B. Phytic acid-trace element ( $\mathrm{Zn}, \mathrm{Cu}, \mathrm{Mn})$ interactions. Int. J. Food Sci. Technol. 2002, 37, 749-758. [CrossRef]

94. Hurrell, R.F. Influence of Vegetable Protein Sources on Trace Element and Mineral Bioavailability. J. Nutr. 2003, 133, 2973S-2977S. [CrossRef] [PubMed]

95. Gawęcki, J.; Woźniewicz, M. Bread and cereal products. In Human Nutrition. Th Base of Nutrition (in Polish); Gawęcki, J., Ed.; Polish Scientific Publishers PWN: Warszawa, Poland, 2010; pp. 340-342. ISBN 9788301163204.

96. Manganese. Linus Pauling Institute. Oregon State University. Available online: https://lpi.oregonstate.edu/ $\mathrm{mic} /$ minerals / manganese (accessed on 17 March 2019). 
97. Hope, S.J.; Daniel, K.; Gleason, K.L.; Comber, S.; Nelson, M.; Powell, J.J. Influence of tea drinking on manganese intake, manganese status and leucocyte expression of MnSOD and cytosolic aminopeptidase P. Eur. J. Clin. Nutr. 2005, 60, 1-8. [CrossRef] [PubMed]

98. Podwika, W.; Kleszcz, K.; Krośniak, M.; Zagrodzki, P. Copper, Manganese, Zinc, and Cadmium in Tea Leaves of Different Types and Origin. Biol. Trace Elem. Res. 2017, 183, 1-17. [CrossRef]

99. Polechońska, L.; Dambiec, M.; Klink, A.; Rudecki, A. Concentrations and solubility of selected trace metals in leaf and bagged black teas commercialized in Poland. J. Food Drug Anal. 2015, 23, 1-17. [CrossRef] [PubMed]

100. Samaniego-Vaesken, L.; Partearroyo, T.; Olza, J.; Aranceta-Bartrina, J.; Gil, Á.; González-Gross, M.; Ortega, R.M.; Serra-Majem, L.; Varela-Moreiras, G. Iron Intake and Dietary Sources in the Spanish Population: Findings from the ANIBES Study. Nutrients 2017, 9, 203. [CrossRef]

101. Rehm, C.D.; Drewnowski, A. Replacing American breakfast foods with ready-to-eat (RTE) cereals increases consumption of key food groups and nutrients among US children and adults: Results of an NHANES modeling study. Nutrients 2017, 9. [CrossRef]

102. Deshmukh-Taskar, P.R.; Nicklas, T.A.; O'Neil, C.E.; Keast, D.R.; Radcliffe, J.D.; Cho, S. The Relationship of Breakfast Skipping and Type of Breakfast Consumption with Nutrient Intake and Weight Status in Children and Adolescents: The National Health and Nutrition Examination Survey 1999-2006. J. Am. Diet. Assoc. 2010, 110, 869-878. [CrossRef]

103. Drewnowski, A.; Rehm, C.; Vieux, F. Breakfast in the United States: Food and Nutrient Intakes in Relation to Diet Quality in National Health and Examination Survey 2011-2014. A Study from the International Breakfast Research Initiative. Nutrients 2018, 10, 1200. [CrossRef] [PubMed]

104. Walker, P.; Rhubart-Berg, P.; Mckenzie, S.; Kelling, K.; Lawrence, R.S. Public health implications of meat production and consumption. Public Health Nutr. 2005, 8, 348-356. [CrossRef] [PubMed]

105. Richi, E.B.; Baumer, B.; Conrad, B.; Darioli, R.; Schmid, A.; Keller, U. Health Risks Associated with Meat Consumption: A Review of Epidemiological Studies. Int. J. Vitam. Nutr. Res 2015, 85, 70-78. [CrossRef]

106. Sharma, S.; Sheehy, T.; Kolonel, L.N. Contribution of meat to vitamin B ${ }_{12}$, iron and zinc intakes in five ethnic groups in the USA: implications for developing food-based dietary guidelines. J. Hum. Nutr. Diet. 2013, 26, 156-168. [CrossRef] [PubMed]

107. Wyness, L. The role of red meat in the diet: Nutrition and health benefits. Proc. Nutr. Soc. 2016, 75, $227-232$. [CrossRef]

108. Pilis, W.; Stec, K.; Zych, M.; Pilis, A. Health benefits and risk associated with adopting a vegetarian diet. Rocz. Państwowego Zakładu Hig. 2014, 65, 9-14.

109. Marsk, K.A.; Munn, E.A.; Baines, S.K. Protein and vegetarian diets. Med. J. Aust. 2013, 199, S7-S10. [CrossRef]

110. Position of the American Dietetic Association: Vegetarian Diets. J. Am. Diet. Assoc. 2009, 109, $1266-1282$. [CrossRef]

111. Finnamore, H.E.; Whelan, K.; Hickson, M.; Shovlin, C.L. Top dietary iron sources in the UK. Br. J. Gen. Pract. 2014, 64, 172-173. [CrossRef]

112. Andrade, G.C.; da Costa Louzada, M.L.; Azeredo, C.M.; Ricardo, C.Z.; Martins, A.P.B.; Levy, R.B. Out-of-home food consumers in Brazil: What do they eat? Nutrients 2018, 10, 218. [CrossRef]

113. Troesch, B.; Biesalski, H.K.; Bos, R.; Buskens, E.; Calder, P.C.; Saris, W.H.M.; Spieldenner, J.; Verkade, H.J.; Weber, P.; Eggersdorfer, M. Increased intake of foods with high nutrient density can help to break the intergenerational cycle of malnutrition and obesity. Nutrients 2015, 7, 6016-6037. [CrossRef] [PubMed]

114. Denney, L.; Afeiche, M.C.; Eldridge, A.L.; Villalpando-Carrión, S. Food sources of energy and nutrients in infants, toddlers, and young children from the Mexican National Health and Nutrition Survey 2012. Nutrients 2017, 9. [CrossRef] [PubMed]

115. Sicińska, E.; Wyka, J. Folate Intake in Poland on the Basis of Literature (in Polish). Rocz. Państwowego Zakładu Hig. 2011, 62, 247-256.

116. Drewnowski, A. Concept of a nutritious food: toward a nutrient density score1-3. Am. J. Clin. Nutr. 2005, 82, 721-732. [CrossRef] 
117. Jarosz, M. Pyramid of Healthy Eating and Physical Activity for Adults (in Polish). Available online: https://ncez.pl/abc-zywienia-/zasady-zdrowego-zywienia/piramida-zdrowego-zywienia-iaktywnosci-fizycznej-dla-osob-doroslych (accessed on 30 January 2019).

118. A Healthy and Sustainable Food Future: Policy recommendations to embed sustainability in the Eatwell Guide and wider UK food policy. Available online: https:/ / www.eating-better.org/uploads/Documents / AHealthySustainableFoodFuture(1).pdf (accessed on 4 March 2019). 